\title{
Dilemma of Top Athletes in Choosing Their Studies
}

\author{
Mateja Gorenc PhD \\ International School for Social and Business Studies \\ mateja.gorenc@gmail.com
}

\author{
Mojca Braz PhD student \\ Faculty of Commercial and Business Sciences \\ braz.mm@gmail.com
}

Purpose: The purpose of the research was to determine whether satisfaction with the choice of studies of top Slovenian athletes affects sports performance and whether the sports performance affects the study performance.

Study design/methodology/approach: We surveyed 112 top Slovenian athletes. The data used in the quantitative survey was based on a selected sample of top athletes, primarily members of the SLO Olympic Team. We used linear multiple regression analysis (the Enter method so that all of the selected variables were included in the model simultaneously. The Enter method shows us all of the variables in the results, even if their influence is not statistically significant). From each factor, we obtained the average value of the responses, which were processed with Pearson's correlation coefficient and regression analysis. We measured the Study performance and the Sports performance with the Likert scale from 1 to 5 .

Findings: We found from the research that if a top athlete is satisfied with the choice of studies, the study performance (linear, positive, and high correlation) will consequently increase. We also found that if the performance in sports increases, this results in a decrease in the study performance (linear, negative, and low correlation).

Originality/value: The conducted research determined the success factors of dual careers of top Slovenian athletes because so far, there has been little research focusing on the factors related to the successful outside-of-sports (Academic) careers of athletes.

\section{Introduction}

Athletes in Slovenia have different status rights, and these status rights are related to categorization. A categorized athlete is a registered athlete who holds the title of a world-class athlete, international athlete, prospective athlete, national athlete, and youth athlete.

The title of top or consummate athlete is obtained by a citizen of the Republic of Slovenia who achieves a sporting achievement of international, world, or Olympic class, and is thus entered in the register of registered and categorized athletes (Sports Act, 2017). Furthermore, a top athlete can acquire the right to health, accident, pension, disability insurance, maternity leave, and adjustment of obligations in the educational program. In return, the top athlete must participate in the national teams' performances and act following the international rules and the rules of national sports federations, and the norms of sports ethics and morals.

The career of a top athlete is relatively short, and only a few athletes can secure financial resources during their active sports career that would be sufficient to enable them to survive after their completed sports career. Therefore, the top athletes must start thinking about how they will provide for themselves after completing their sports careers as early as during their active sports careers. In addition, with completed education and acquired professions, athletes have a much better starting point for competing in the labor market.

The state also has interests to have as many top (recognizable) athletes as possible for the citizens to identify with, enhancing national awareness and state visibility (promotion). At the same time, successful athletes also result in the greater involvement of young people and adults in sports activities. This, in turn, enhances citizens' health and brings other social, cultural, and 
infrastructural benefits. The question, however, is what the country is prepared to do to help educate active athletes.

\section{Sport and Education}

Athletes need to be responsible, committed, and adaptable to the adjustments offered to them by universities to avoid a situation where they are forced to choose between education and sport (European Commission, 2012).

According to Article 35 of the ZŠpo-1 Sports Act, an athlete has the recognized right to adjust school and study obligations and alter the Matura exam's conduct in Slovenia. Moreover, according to the article, an athlete can exercise the right to enrolment into further education.

Top athletes undergo a tremendous amount of training, which is often difficult to reconcile with educational obligations. A dual career (successful combination of a top sport and education) is a multidimensional process influenced by the individual (talent and psychological characteristics), interpersonal relationships (social support and cultural customs), the environment (access and availability of services), and politics (national and international norms). Different approaches to dual careers of athletes in various European countries are leading to varying careers for athletes. By protecting athletes' rights to engage in sports and education concurrently, European policymakers have begun to encourage EU Member States to support student-athletes at a local level by following the EU dual-career athlete guidelines and key actions. Within this framework, since 2004, the European Network for StudentAthletes has actively been supporting the EU's efforts to promote a dual career by providing a platform for a better dialogue between educational institutions (universities, colleges, sports schools) and sports organizations (clubs and sports federations). By promoting networking of institutions, the European Network for Student-Athletes aims to unify partners involved in top sports and education, promote the exchange of best practices in the field of dual-career athletes, strengthen links between education and sports organizations, and support and participate in projects and research on dual careers (Capranica et al., 2015).

EU dual-career guidelines (i.e., Sport and Education) encourage Member States to provide adequate services to support the dual careers of top student-athletes. The studies aimed to examine: a) student athletes' views on their sports and academic careers and b) existing and possible service delivery supporting dual careers. A 25-question semi-structured questionnaire was sent to 221 top European athletes involved in individual and team sports at national and international levels. They found differences $(\mathrm{p}<=0.05)$ regarding nationality, type of sport, and level of competition. Female athletes put more effort into their academic careers, and athletes involved in individual sports also spoke about insufficient support from academic staff. In addition, athletes competing in an international environment have perceived that giving priority to the sport has a more significant impact on their academic careers than other peers from their home country. Low results have been found in considering dual careers in academic and sporting settings, supporting the faculty staff, and coordinating schedules at academic and athletic levels. In general, student-athletes required the provision services at an academic level (i.e., flexibility, online education) and the level of support. National academic and sports systems influence the opinion of student-athletes about their dual careers, especially at the top level of sports. In the EU Member States, flexibility, distance learning, and coaching should be improved (Fuchs et al., 2016).

Since 2016, the situation in the field of dual careers of top athletes has been improving in Slovenia as the Association of Sports Federations (OKS-ZŠZ) has been running activities and programs to support athletes and coordinating both careers. The Associaton is also supported by the Ministry of Education, Science, and Sport (MIZŠ). Sorkkila et al. (2020) published that 
massive numbers of adolescents participate in organized sport during their education years worldwide. For example, in the USA, more than 400.000 students participate in intercollegiate athletic programs yearly, whereas, in Canada, $84 \%$ of young adolescents have reported participating in sports. So in Slovenia, OKS and MIZS introduced the "Athlete-friendly education" certificate, which is awarded to educational institutions at the secondary and higher levels of education based on specific criteria and standards, as well as assessment rules.

Costa (2020) means that countries that offer places in higher education have more explicit sports organization and hierarchy, enabling scholarships to develop athletes (whether high-income, elite or student-athletes), considering their dedication to sport and studies. Akosah-Twumasi et al. (2018) found that providing accessible sources of support and empowering youths to discuss their concerns related openly to career decision-making will broaden the youth's understanding, significantly impacting their academic and career pathways. Clarke (1975; in Sivec, 2005) believes that athletes score as high as non-athletes, some even higher. In Slovenia, similar results have been obtained in the research of Jurak, Kovač, and Strel (2003 and 2005), in which high school athletes achieve similar overall success at the Matura exam as their peers and slightly above average in compulsory Matura subjects. In their studies, Adler and Adler (1999; in Sivec, 2005) find that some athletes gain experience during their study at university, some transition to professional ranks. However, many of them are rudely thrown back into the society in which they are no longer appreciated or favoured. They are forgotten as quickly as they appeared and became influential.

\section{Research purpose}

The purpose of the research was to determine whether satisfaction with the choice of studies affects sports performance and whether sports performance affects the study performance. Based on the questions, we posed two research hypotheses.

Hypothesis 1: Satisfaction with the choice of studies has a positive effect on study performance. Hypothesis 2: Sports performance negatively affects study performance.

\section{Researched methods in use}

A quantitative method was used to collect the data. We prepared and conducted an online survey in 2018, and it lasted until 2019 since all the relevant information support had to be provided for its implementation. The questionnaire was sent to over 400 athletes in Slovenia. We selected the segment of respondents in the Club of Olympians who had a career of top athletes in their active years, during which they did or did not decide on an academic career. The online survey was conducted from 5 April 2018 to 23 October 2019. The survey was successfully carried out and completed on 23 October 2019.

Hypothesis 1 and Hypothesis 2 were tested based on a survey carried out among athletes who coordinated studies and sport. We used linear multiple regression analysis (the Enter method so that all of the selected variables were included in the model simultaneously. The Enter method shows us all of the variables in the results, even if their influence is not statistically significant). From each factor, we obtained the average value of the response, which was processed with Pearson's correlation coefficient and regression analysis. I measured the Study performance and the Sports performance with the Likert scale from 1 to 5.

\section{Results of the empirical research}

In this chapter, we present the results of the quantitative survey (Questionnaire). When testing hypotheses, we show the operationalization of the variables and the structure of the measuring 
instrument (online survey questionnaire). As part of the statistical analysis, we present the descriptive statistics and the results of the hypotheses.

\section{Research sample}

A total of 396 respondents participated in the quantitative survey, of which 165 agreed to complete the survey, of which 112 produced valid questionnaires. We eliminated 53 questionnaires as they were not filled in. Therefore, the quantitative research sample is $\mathrm{N}=112$, represented by athletes in the Republic of Slovenia, aged 19 to 76 years. Tables 1 to 8 show the demographic data of the respondents.

Table 1: Gender

\begin{tabular}{|l|r|l|}
\hline Gender & Frequency & Percentage \\
\hline Male & 76 & $68 \%$ \\
\hline Female & 36 & $32 \%$ \\
\hline Total & 112 & $100 \%$ \\
\hline
\end{tabular}

Source: Author's own source

Table 1 shows the gender of the respondents. $68 \%$ were men, and $32 \%$ were women.

Table 2: Age

\begin{tabular}{|l|r|r|}
\hline Age & Frequency & Percentage \\
\hline up to 30 years & 24 & $21 \%$ \\
\hline 31 to 40 years & 22 & $20 \%$ \\
\hline 41 to 50 years & 34 & $30 \%$ \\
\hline over 50 years & 32 & $29 \%$ \\
\hline Total & 112 & $100 \%$ \\
\hline
\end{tabular}

Source: Author's own source

Table 2 shows the age of the respondents. The age of the respondents was divided into four classes. $21 \%$ were under 30 years of age, $20 \%$ were from 31 to 40 years of age, $30 \%$ were from 41 to 50 years of age, and $29 \%$ were over 50 .

Table 3: Current involvements in sports

\begin{tabular}{|l|r|r|}
\hline Current involvements in sports & Frequency & Percentage \\
\hline Yes & 72 & $64 \%$ \\
\hline No & 40 & $36 \%$ \\
\hline Total & 112 & $100 \%$ \\
\hline
\end{tabular}

Source: Author's own source

Table 3 shows the respondents' current involvement in sports. Again, 64\% of the respondents are still active athletes, and $36 \%$ are no longer involved in sports.

Table 4: Current involvement in the studies

\begin{tabular}{|l|r|r|}
\hline Current involvement in the studies & Frequency & Percentage \\
\hline I am a full-time student in Slovenia & 10 & $9 \%$ \\
\hline I am a part-time student in Slovenia & 4 & $4 \%$ \\
\hline A graduate student (extra year) & 2 & $2 \%$ \\
\hline Completed studies in Slovenia & 71 & 4 \\
\hline Completed studies abroad & 2 & $64 \%$ \\
\hline After the finished career, I am continuing my studies & 2 & $4 \%$ \\
\hline I have not studied & 9 & $2 \%$ \\
\hline I do not intend to studies & 2 & $2 \%$ \\
\hline I have not studied & 6 & $7 \%$ \\
\hline Other: & $2 \%$ \\
\hline Total & 112 & $5 \%$ \\
\hline
\end{tabular}


Table 4 shows current involvement in the studies. $64 \%$ of the respondents have completed their studies in Slovenia, and 4\% have completed their studies abroad. 9\% of the respondents study full-time in Slovenia, and 4\% are studying part-time in Slovenia. 2\% of the respondents are graduates. $2 \%$ of the respondents continue their studies after the completed careers, and $2 \%$ still intend to study. $7 \%$ of the respondents do not intend to study, $2 \%$ have never studied.

Table 5: Name of the educational institution where you have studied (or are studying)

\begin{tabular}{|c|c|c|}
\hline Name of the educational institution where you studied (are still studying) & Frequency & Percentage \\
\hline Faculty of Sport, University of Ljubljana & 17 & $14 \%$ \\
\hline Faculty of Civil and Geodetic Engineering, University of Ljubljana & 11 & $11 \%$ \\
\hline Faculty of Economics, University of Ljubljana & 10 & $9 \%$ \\
\hline Faculty of Commercial and Business Sciences & 10 & $9 \%$ \\
\hline Faculty of Economics and Business, University of Maribor & 8 & $7 \%$ \\
\hline Other: & 8 & $7 \%$ \\
\hline Faculty of Arts, University of Ljubljana & 6 & $5 \%$ \\
\hline Faculty of Medicine, University of Ljubljana & 6 & $5 \%$ \\
\hline Faculty of Humanities, University of Primorska & 4 & $4 \%$ \\
\hline Biotechnical Faculty, University of Ljubljana & 4 & $4 \%$ \\
\hline Faculty of Electrical Engineering, University of Ljubljana & 4 & $4 \%$ \\
\hline Faculty of Education, University of Ljubljana & 4 & $4 \%$ \\
\hline Faculty of Organizational Sciences, University of Maribor & 4 & $4 \%$ \\
\hline Faculty of Education, University of Primorska & 2 & $2 \%$ \\
\hline Faculty of Social Sciences, University of Ljubljana & 2 & $2 \%$ \\
\hline Faculty of Pharmacy, University of Ljubljana & 2 & $2 \%$ \\
\hline Faculty of Chemistry and Chemical Technology, University of Ljubljana & 2 & $2 \%$ \\
\hline Faculty of Mathematics and Physics, University of Ljubljana & 2 & $2 \%$ \\
\hline Faculty of Computer and Information Science, University of Ljubljana & 2 & $2 \%$ \\
\hline Faculty of Security Sciences, University of Maribor & 2 & $2 \%$ \\
\hline Faculty of Organizational Studies in Novo mesto & 2 & $2 \%$ \\
\hline Total & 112 & $100 \%$ \\
\hline
\end{tabular}

Source: Author's own source

Table 5 shows the name of the educational institution the respondents have studied at or are still studying. A maximum of $14 \%$ of the respondents has studied at the Faculty of Sports, followed by the Faculty of Economics.

Table 6: Completed level of education

\begin{tabular}{|c|c|c|}
\hline Completed level of education & Frequency & Percentage \\
\hline Primary school or less (I and II) & 2 & $2 \%$ \\
\hline Secondary Vocational Education (IV) & 2 & $2 \%$ \\
\hline $\begin{array}{l}\text { Grammar, secondary vocational-technical education, secondary technical or other } \\
\text { vocational education }(\mathrm{V})\end{array}$ & 14 & $13 \%$ \\
\hline College program (up to 1994), Vocational college program (VI / 1) & 4 & $4 \%$ \\
\hline Specialization after college, Professional higher education programs (VI / 2) & 4 & $4 \%$ \\
\hline Higher Education Professional and University Program (1st year) (VI / 2) & 17 & $14 \%$ \\
\hline Specialization after Higher Education Prof. Program, University Program (VII) & 36 & $32 \%$ \\
\hline Master's degree (2nd year) (VII) & 14 & $13 \%$ \\
\hline Specialization after University Program, Master of Science (VIII / 1) & 10 & $9 \%$ \\
\hline $\mathrm{PhD}(\mathrm{VIII} / 2)$ & 5 & $5 \%$ \\
\hline PhD (3rd level of Bologna system) (VIII / 2) & 4 & $4 \%$ \\
\hline Total & 112 & $100 \%$ \\
\hline
\end{tabular}


I was interested in the level of education that the participants in the survey achieved, so Table 6 shows their completed level of education. The majority (32\%) of the respondents have completed a Specialization after Higher Education Professional Program, University Program (VII).

Table 7: Sports discipline

\begin{tabular}{|c|c|c|c|c|c|}
\hline Sports discipline: & Frequency & Percentage & Sports discipline: & Frequency & Percentage \\
\hline athletics - stadium & 6 & $5 \%$ & tennis & 2 & $2 \%$ \\
\hline gymnastics - sports & 6 & $5 \%$ & $\begin{array}{l}\text { dance - acrobatic } \\
\text { R\&R }\end{array}$ & 2 & $2 \%$ \\
\hline sailing & 2 & $2 \%$ & $\begin{array}{l}\text { dance - modern } \\
\text { competitive dances }\end{array}$ & 4 & $4 \%$ \\
\hline judo & 2 & $2 \%$ & ice skating - artistic & 2 & $2 \%$ \\
\hline cycling - road & 4 & $4 \%$ & karate & 2 & $2 \%$ \\
\hline basketball & 6 & $5 \%$ & $\begin{array}{l}\text { aviation } \\
\text { modelling }\end{array}$ & 2 & $2 \%$ \\
\hline table tennis & 8 & $7 \%$ & weight lifting & 2 & $2 \%$ \\
\hline football & 4 & $4 \%$ & golf & 14 & $13 \%$ \\
\hline volleyball & 14 & $13 \%$ & fencing & 2 & $2 \%$ \\
\hline swimming & 2 & $2 \%$ & $\begin{array}{l}\text { skiing - } \\
\text { biathlon - shi }\end{array}$ & 2 & $2 \%$ \\
\hline handball & 4 & $4 \%$ & $\begin{array}{l}\text { skiing - ski-run - } \\
\text { shi }\end{array}$ & 4 & $4 \%$ \\
\hline skiing - Alpine & 6 & $5 \%$ & squash & 4 & $4 \%$ \\
\hline skiing - biathlon & 2 & $2 \%$ & Other: & 2 & $2 \%$ \\
\hline shooting & 2 & $2 \%$ & Total & 112 & $100 \%$ \\
\hline
\end{tabular}

Source: Author's own source

Table 7 shows the sport disciplines in which the respondents are or have been engaged. Most respondents are or have been involved in volleyball and golf.

Table 8: Slovenian Olympic Committee categorization

\begin{tabular}{|l|r|r|}
\hline Slovenian Olympic Committee categorization & Frequency & Percentage \\
\hline Olympic Categorization Class & 2 & $2 \%$ \\
\hline World-class & 12 & $11 \%$ \\
\hline International class & 34 & $30 \%$ \\
\hline Perspective class & 12 & $11 \%$ \\
\hline National class & 34 & $30 \%$ \\
\hline Youth class & 2 & $2 \%$ \\
\hline No categorization & 14 & $13 \%$ \\
\hline Other: & 2 & $2 \%$ \\
\hline Total & 112 & $100 \%$ \\
\hline
\end{tabular}

Source: Author's own source

Table 8 shows categorization according to the Slovenian Olympic Committee. Most of the respondents are in the international and national classes.

\section{Descriptive statistics}

The key characteristics of the data are expressed using descriptive statistics methods. For example, the standard deviation tells how the data is scattered around the arithmetic mean. A high standard deviation value means that the values are more scattered, and a low one means that they are more concentrated around the arithmetic mean. 
In the beginning, we were interested in the respondents' own assessments of their success in coordinating a dual career. Therefore, all responses were rated on a scale of 1 to 5 , with 1 meaning "not at all" for the selected score and 5 meaning "exceptional."

Table 9: Assessment of own performance in different areas

\begin{tabular}{|l|r|r|r|r|r|}
\hline $\begin{array}{l}\text { Evaluate your own performance in different } \\
\text { areas. }\end{array}$ & N & Min & Max & AS & \multicolumn{1}{l|}{ SD } \\
\hline Successful dual-career coordination & 108 & 1 & 5 & 3,67 & 0,947 \\
\hline Sport performance & 112 & 2 & 5 & 3,80 & 0,769 \\
\hline Study performance & 112 & 1 & 5 & 3,88 & 0,807 \\
\hline Performance in the profession & 106 & 3 & 5 & 4,13 & 0,618 \\
\hline
\end{tabular}

Legend: $\mathbf{M i n}=$ minimum; $\mathbf{M a x}=$ maximum; $\mathbf{A S}=$ Arithmetic mean; $\mathbf{S D}=$ Standard deviation

\section{Source: Author's own source}

Table 9 presents descriptive statistics for each answer. The respondents rated their performance in the profession the highest $(\mathrm{AS}=4.13, \mathrm{SD}=0.618)$, followed by study performance ( $\mathrm{AS}=$ $3.88, \mathrm{SD}=0.807)$ and sports performance $(\mathrm{AS}=3.80, \mathrm{SD}=0.769)$, above the middle of the scale is also the lowest rated - successful dual career coordination $(\mathrm{AS}=3.67, \mathrm{SD}=0.947)$.

We wanted to explore how successful the coordination of sport and studies was. Table 10 presents the response frequencies of the respondents and the response frequencies in per cent for each answer. The cumulative frequency is also presented.

Table 10: Coordination of sport and studies

\begin{tabular}{|c|c|c|c|c|}
\hline How were your sport and studies coordinated: & Frequency & Percentage & Valid & Cumulative \\
\hline $\begin{array}{l}\text { During my active sports career, I completed my studies within } \\
\text { the prescribed period (length of studies and seniority) }\end{array}$ & 24 & $21 \%$ & $21 \%$ & $21 \%$ \\
\hline $\begin{array}{l}\text { During my active sports career, I completed my studies within } \\
\text { one year after the prescribed deadline (length of studies and } \\
\text { seniority) }\end{array}$ & 24 & $21 \%$ & $21 \%$ & $43 \%$ \\
\hline $\begin{array}{l}\text { During my active sports career, I completed my studies within } \\
\text { more than one year after the prescribed deadline (length of } \\
\text { studies and seniority) }\end{array}$ & 24 & $21 \%$ & $21 \%$ & $64 \%$ \\
\hline $\begin{array}{l}\text { I completed my studies after completing my sports career } \\
\text { within more than one year after the prescribed deadline (length } \\
\text { of studies and seniority) }\end{array}$ & 14 & $13 \%$ & $13 \%$ & $77 \%$ \\
\hline $\begin{array}{l}\text { I completed my studies after completing my sports career } \\
\text { within the prescribed time limit (length of studies and } \\
\text { seniority) }\end{array}$ & 16 & $14 \%$ & $14 \%$ & $91 \%$ \\
\hline I have not completed the studies & 4 & $4 \%$ & $4 \%$ & $95 \%$ \\
\hline I have not studied & 2 & $2 \%$ & $2 \%$ & $96 \%$ \\
\hline Other: & 4 & $4 \%$ & $4 \%$ & $100 \%$ \\
\hline Total: & 112 & $100 \%$ & $100 \%$ & \\
\hline
\end{tabular}

Source: Author's own source

Table 10 shows surprising data on the coordination of sports and studies, as most athletes (90\%) completed their studies during an active sports career, only 4\% did not complete their studies, and $2 \%$ did not choose to study. One-fifth of the respondents completed their studies within the prescribed deadline or one year after the prescribed deadline, and a fifth required more than one year after the prescribed deadline for the completion of the studies. More than a quarter of the respondents completed their studies after the end of their career $(14 \%$ within one year after the prescribed deadline, and 13\% within the prescribed deadline).

The answers show that the coordination is complex, as only $21 \%$ of the athletes completed their studies within the prescribed period during their active sports career. However, $90 \%$ of the 
surveyed students completed their studies during or shortly after finishing their sports careers indicates that this is a group of highly motivated people.

When young people decide to study, they choose among the areas that interest them and the professions that would offer them satisfaction in later life. At the same time, the choice of studies must be such that it is possible to coordinate studies and sport.

The answers to the survey that best describe the variable satisfaction with different areas of dual-career are presented in Table 11. All the responses were rated on a scale of 1 to 5, with 1 meaning "Not at all satisfied" and 5 meaning "Very satisfied."

Table 11: Satisfaction with different areas of the dual career

\begin{tabular}{|l|l|r|r|r|r|}
\hline $\begin{array}{l}\text { How satisfied are you with the different areas of the } \\
\text { dual-career decision? }\end{array}$ & N & Min & Max & AS & \multicolumn{1}{l|}{ SD } \\
\hline Coordinating sport and studies & 110 & 1 & 5 & 3,56 & 0,894 \\
\hline Choice of studies & 110 & 2 & 5 & 4,13 & 0,940 \\
\hline Study performance & 110 & 2 & 5 & 3,91 & 0,749 \\
\hline Sports career & 110 & 2 & 5 & 3,75 & 0,795 \\
\hline Dual career decision & 110 & 2 & 5 & 4,00 & 0,857 \\
\hline
\end{tabular}

Legend: Min = minimum; $\mathbf{M a x}=$ maximum; $\mathbf{A S}=$ Arithmetic mean; $\mathbf{S D}=$ Standard deviation

Source: Author's own source

The results show that the athletes are satisfied with their dual-career decision based on the assessment that the choice of studies is the highest-rated.

\section{Multivariate analysis}

Below, we present multivariate analyses of the correlations among the studied variables. The basis for understanding the correlations among the variables and the first key condition for performing a linear regression analysis is determining the mutual correlations between pairs of independent variables and between independent and dependent variables. In the following tables, we present a summary of the regression analysis (values of correlation coefficients, values of determination, or adjusted determination coefficients), F-test (ANOVA) with which we tested the hypotheses. Based on the obtained results, we confirmed or rejected the hypotheses.

The first hypothesis is:

H1: Satisfaction with the choice of studies has a positive effect on study performance.

To test the first hypothesis - H1, we checked the correlations between the Satisfaction with the choice of studies and Study performance variables. The correlation between these two variables is tested with the following population regression model and hypothesis.

Population regression model:

Satisfaction with the choice of studies $=\beta 1+\beta 2 *$ Study performance $+u$

Hypothesis:

$H_{0}: \beta_{2}=0$

$H_{1:} \beta_{2} \neq 0$ 
The H1 hypothesis was tested using the linear regression analysis (Enter method), where the dependable variable is Satisfaction with the choice of studies and is the independent variable is Study performance.

Table 12: Linear regression - $\mathrm{H1}$

\begin{tabular}{|l|r|r|rr|lr|}
\hline & & & & & \\
Model & R & \multicolumn{1}{|l|}{$\mathbf{R}^{\mathbf{2}}$} & Adjusted R & Std. Error of the Estimate \\
\hline 1 & & $0,507^{\mathrm{a}}$ & 0,257 & 0,250 & & 0,814 \\
\hline
\end{tabular}

a. Independent variable: Study performance

In Table 12, the R multiple correlation coefficient shows the strength of the correlation between the dependent variable (Satisfaction with the choice of study) and the independent variable (Study performance). The R multiple correlation coefficient is 0.507 , indicating a medium correlation. The multiple coefficient of determination explains that $25 \%$ of the total variance can be explained by the influence of the independent variable, which represents $75 \%$ of the unexplained influence.

Table 13: Linear regression - ANOVA table - H1

\begin{tabular}{|c|c|c|c|c|c|}
\hline Model & Sum of squares & sp & Average square & $\mathbf{F}$ & p-value \\
\hline 1 Regression & 24,727 & 1 & 24,727 & 37,355 & ,000 \\
\hline Residual & 71,491 & 108 & 0,662 & & \\
\hline Total & 96,218 & 109 & & & \\
\hline
\end{tabular}

a. Dependent variable: Satisfaction with the choice of studies

b. Independent variables: Study performance

In Table 13, the p-value is $0.000<0.05$, and we can say that our model is statistically significant at $5 \%$ risk.

Table 14: Linear regression - model coefficients - H1

\begin{tabular}{|c|c|c|c|c|c|}
\hline \multirow[b]{2}{*}{ Model } & \multicolumn{2}{|c|}{ Understand. coefficients } & \multirow{2}{*}{$\begin{array}{l}\text { Stand. coefficients } \\
\text { Beta }\end{array}$} & \multirow[b]{2}{*}{$\mathbf{t}$} & \multirow[b]{2}{*}{ p-value } \\
\hline & $\beta$ & St. error & & & \\
\hline 1 (Constant) & 1,504 & 0,436 & & 3,448 & 0,001 \\
\hline Study performance & 0,668 & 0,109 & 0,507 & 6,112 & 0,000 \\
\hline
\end{tabular}

a. Dependent variable: Satisfaction with studies choice

Table 6 examined the statistical characteristics of the $(\beta)$ standardized regression coefficient and the $\mathrm{p}$-values to test the $\mathrm{H} 1$ hypothesis. A significance level greater than 0.05 indicates no influence of the independent variable on the dependent variable. Therefore, based on the obtained results and the value of the $\beta$ regression coefficient, we can confirm the H1 hypothesis and conclude that the dependent variable Satisfaction with the choice of study is influenced by Study performance.

From Figure 1, we can see that there is a positive and linear correlation between the Satisfaction with the choice of study dependent variable and the Study performance independent variable. 


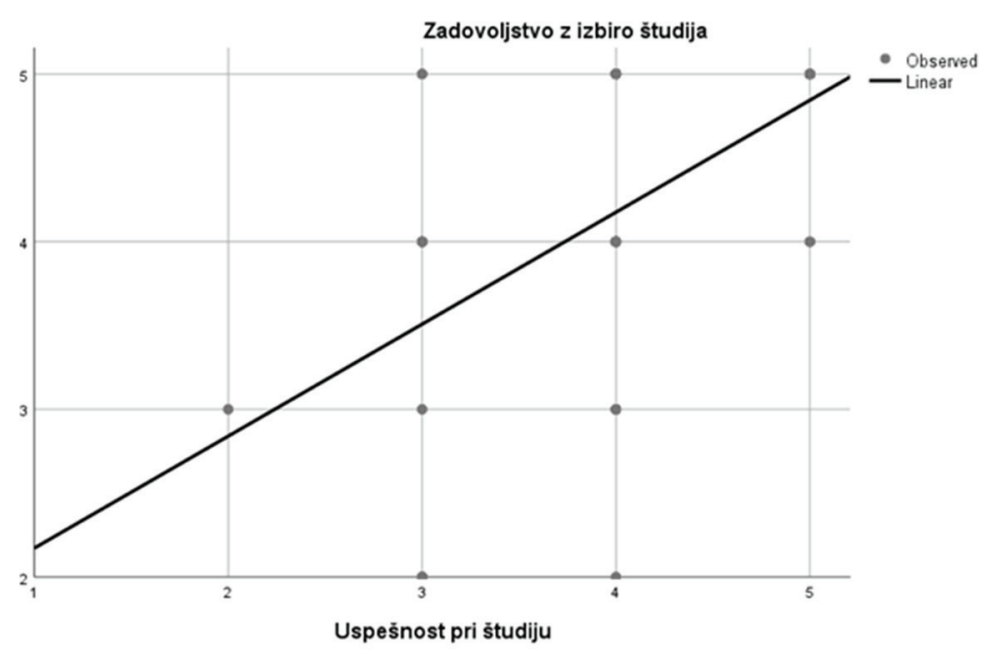

Figure 1: Linear correlation between the Satisfaction with the choice of studies dependent variable and the Study performance independent variable

The second hypothesis is:

H2: Sports performance negatively affects Study performance.

To test the second - H2 - hypothesis, we checked the correlation between the Sports performance and Study performance variables. The correlation between these two variables is examined with the following population regression model and hypothesis.

Population regression model:

Sports performance $=\beta 1+\beta 2 *$ Study performance $+u$

Hypothesis:

$H_{0}: \beta_{2}=0$

$H_{1}: \beta_{2} \neq 0$

The H2 hypothesis was tested by the linear regression analysis (Enter method), where Sports performance is the dependent variable and Study performance the independent variable.

Table 15: Linear regression - $\mathrm{H2}$

\begin{tabular}{|c|c|c|c|c|}
\hline Model & $\mathbf{R}$ & $\mathbf{R}^{2}$ & Adjusted $\mathbf{R}^{2}$ & Std. Error of the Estimate \\
\hline 1 & $0,272^{\mathrm{a}}$ & 0,074 & 0,066 & 0,744 \\
\hline
\end{tabular}

a. Independent variable: Study performance

In Table 15, the R multiple correlation coefficient shows the strength of the correlation between Sports performance (the dependent variable) and Study performance (the independent variable). The $\mathrm{R}$ multiple correlation coefficient is 0.272 , indicating a low correlation. The multiple coefficient of determination explains that $6.6 \%$ of the total variance can be explained by the influence of the independent variable, which represents $93.4 \%$ of the unexplained influence. 
Table 16: Linear regression - ANOVA table

\begin{tabular}{|c|c|c|c|c|c|}
\hline Model & Sum of squares & sp & Average square & $\mathbf{F}$ & p-value \\
\hline 1 Regression & 4,866 & 1 & 4,866 & 8,802 & $0,004^{\mathrm{b}}$ \\
\hline Residual & 60,813 & 110 & 0,553 & & \\
\hline Total & 65,679 & 111 & & & \\
\hline
\end{tabular}

a. Dependent variable: Sports performance

b. Independent variables: Study performance

In Table 16, the p-value is $0.004<0.05$, and we can say that our model is statistically significant at $5 \%$ risk.

Table 17: Linear regression - model coefficients - H2

\begin{tabular}{|c|c|c|c|c|c|}
\hline \multirow[b]{2}{*}{ Model } & \multicolumn{2}{|c|}{ Understand. coefficients } & \multirow{2}{*}{\begin{tabular}{|l|} 
Stand. coefficients \\
Beta \\
\end{tabular}} & \multirow[b]{2}{*}{$\mathbf{t}$} & \multirow[b]{2}{*}{ p-value } \\
\hline & $\beta$ & St. error & & & \\
\hline 1 (Constant) & 4,809 & 0,346 & & 13,893 & 0,000 \\
\hline Study performance & $-0,260$ & 0,087 & $-0,272$ & $-2,967$ & 0,004 \\
\hline
\end{tabular}

a. Dependent variable: Sports performance

In Table 17, we tested the statistical characteristics of the $(\beta)$ standardized regression coefficient and $\mathrm{p}$ - values to test the $\mathrm{H} 2$ hypothesis. A significance level greater than 0.05 indicates no influence of the independent variable on the dependent variable. Therefore, based on the obtained results and the value of the $\beta$ regression coefficient, we can confirm the H2 hypothesis and conclude that the Sports performance dependent variable is negatively influenced by Study performance.

Figure 2 indicates a negative and linear correlation between the dependent variable - Sports performance - and the independent variable - Study performance.

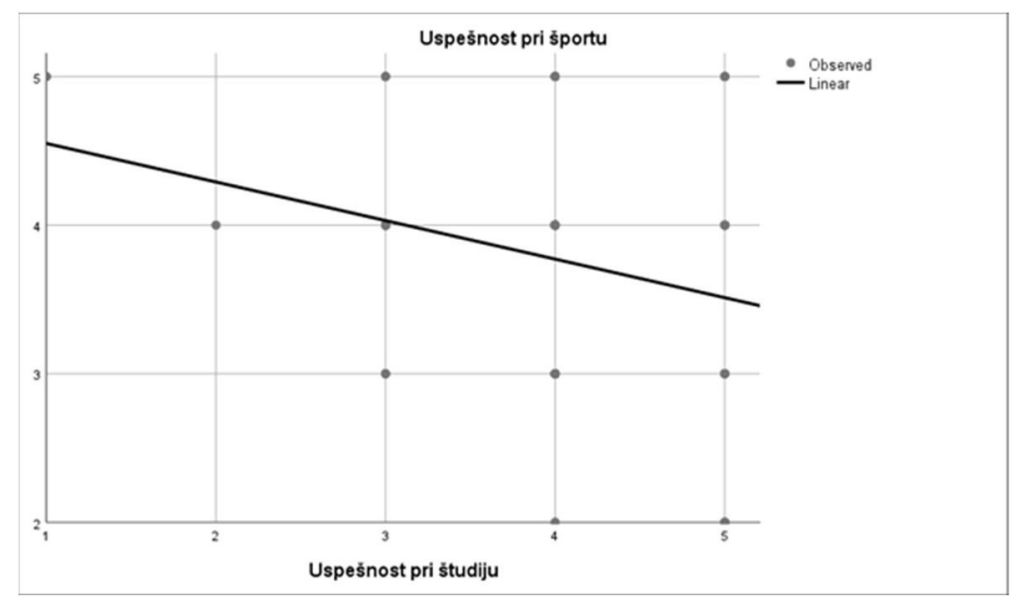

Figure 2: Linear correlation of the dependent variable (Sports performance) and the independent variable (Study performance)

\section{Conclusion}

The purpose of the study was to determine whether study performance is influenced by satisfaction with the choice of study and sports performance. We surveyed 112 Slovenian athletes. $64 \%$ of the respondents are currently still involved in sports, and $36 \%$ are no longer actively involved in sports. $30 \%$ of the respondents are categorized in the international class, and $30 \%$ of the respondents in the national class. $13 \%$ of the respondents are without categorization. $11 \%$ of the respondents are in the World-class, and $11 \%$ of the respondents are in the Perspective class. In addition, $2 \%$ of the respondents are in the Olympic Categorization 
Class, and $2 \%$ of the respondents are in the Youth Class. Based on the analysis, we found that satisfaction with the choice of studies has a positive effect on study performance, and sports performance has a negative impact on study performance.

We have found that if the satisfaction with the choice of study increases, the study performance also increases linearly (linear, positive, and high correlation). Conversely, we have also found that if sports performance increases as a result, study performance decrease (linear, negative, and low correlation).

We have found that $21 \%$ of the respondents completed their studies during their active sports career within the prescribed period (length of studies and seniority). Furthermore, $21 \%$ of the respondents completed their studies during their active sports career within one year after the specified deadline (length of studies and seniority), 21\% of the respondents completed their studies during their active sports career within more than one year after the prescribed deadline (length of studies and seniority), 14\% of the respondents completed their studies after the end of their sports career and within more than one year after the prescribed deadline (length of studies and seniority), $13 \%$ of the respondents completed their studies after the end of their sports career within the prescribed period (length of studies and seniority), $4 \%$ of the respondents did not complete their studies, and $2 \%$ of the respondents have not studied at all. Like others, they stated that they had completed high school on time. It is an exciting result that as many as $90 \%$ of the respondents completed their studies during an active sports career.

\section{References}

Akosah-Twumasi, P., Emeto T.I., Lindsay, D, Tsey, K. andMalau-Aduli, B.S. (2018). A Systematic Review of Factors That Influence Youths Career. Frontiers in Education

Aquilina, D. and Henry, I. (2010). Elite athletes and university education in Europe: A review of policy and practice in higher education in the European UnionMember States. International Journal of Sport Policy, $1(1), 24-47$.

Bednarik, J., Ferenčak, M. and Turšič, N. (2002). Nekatere socialno-ekonomske značilnosti slovenskih športnikov in športnic. Ljubljana: Fakulteta za šport.

Bon, M. (2011). A Sports Career and Education: Characteristics of participants in specialised handball classes. Kinesiologia Slovenica, 17( 1), 15-27.

Brečko, D. (2006). Načrtovanje kariere kot dialog med organizacijo in posameznikom. Ljubljana: Planet GV.

Brewer, B. W., Van Raalte, J. L. in Petitpas, A. J. (2000). Self-identity in sport career transitions. V D. Lavallee in P. Wylleman (ur.), Career transitions in sport: International perspective. Morgantown: Fitness Information Technology.

Capranica, L., Foerster, J., Keldorf, O., Leseur, V., Vandewalle, P., Duopona Tpic, M., Abelkalns, I., Keskitalo, R, Kozsla, T., Figueiredo, A. and Guidotti, F. (2015). The European athlete as student network (»EAS«). Prioritising dual career of European student-athletes. Kinesiologia Slovenica, 21 (2), str 5 - 10.

Corrado, L., Tessitore, A., Capranica, L., Rauter, S. and Doupona Topic, M. (2012). Motivation for a dual career: Italian and Slovenian student-athletes. Kinesiologia Slovenica, 18(3), 47-56.

Costa, F.R. da; Miranda, I.S. de; \& Figueiredo, A.J. (2020). Sport and education: how to develop a proper dual career. Cultura, Ciencia y Deporte.

Cecić Erpič, S. (2002). Konec športne kariere: razvojno-psihološki in športno-psihološki vidiki. Ljubljana: Fakulteta za šport.

Clow, C. T. (2000). Student-athletes perceived value of education: Effects of a career exploration intervention. Doctor Dissertation, Auburn: Auburn University.

Fuchs X., Wagner, H., Hannola, H., Niemisalo, N., Pehme, A., Puhke, R., Marinsek, M., Stermecki, A., Svetec, D., Brown, A., Capranica, L. and Guidotti, F. (2016). European student-athletes perceptions on dual-career outcomes and services. Kinesiologia Slovenica, 22 (2), 31-48.

Gaston-Gayles, J. L. (2005). Academic exploitation. The adverse impact of college athletics on the educational success of minority student-athletes. Seattle Journal for Social Justice, 10(1), 509-583.

Guidotti, F., Lupo, C., Cortis, C., Baldassarre, A. and Capranica, L. (2014). Italian teachers' perceptions regarding talented atypical students: a preliminary studies. Kinesiologia Slovenica, 20 (3), 36 - 46.

Jameson, M. (2007). Stereotype threat impacts college athletes' academic performance. Connecticut: Wesleyan University. 
Jurak, G., Bednarik, J., Plestenjak, G., Kolar, E., Jagodic, T. and Kovač, M. (2007). Sponzorske možnosti slovenskega športa. V Jurak G. Nekateri kazalniki

Jurak, G., Kovač, M. and Strel, J. (2003). Učne možnosti perspektivnih športnikov. V Jurak G., Kovač M. in Strel J., Športno nadarjeni otroci in dijaki $\mathrm{v}$ šoli: analiza nekaterih organizacijskih modelov in priprava strokovnih podlag za nekatere posebne organizacijske oblike v vzgoji in izobraževanju. Ljubljana, Fakulteta za šport.

Kovač, M., Jurak, G. and Strel, J. (2004). Možnosti enakopravnega izobraževanja za dijake športnike. Šport, 52(4), 13-15.

Kovač, M., Kolar, E., Bednarik, J. and Doupona Topič, M. (2005). Vpliv vrhunskih rezultatov na razvoj športa, nacionalno identifikacijo in prepoznavnost Slovenije v Evropi in svetu. V M. Kovač in G. Starc (ur.), Šport in nacionalna identifikacija Slovencev. Ljubljana: Univerza v Ljubljani, Fakulteta za šport, Inštitut za kineziologinjo.

Mikolavčič, M. (2010). Poklicna kariera vrhunskega športnika po končani športni poti. (Diplomsko delo). Ljubljana: Fakulteta za šport.

Ogilvie, B. C. and Taylor, J. (1993). Career termination issues among elite athletes. Handbook of research on sports psychology (761-779). New York: Macmillan publishing company.

Pettaway Willis, K. J. (2005). Female basketball student-athletes motivation: Analysing academic standing and ethnicity at Atlantic coast conference institutions. Doctoral dissertation, Florida: The Florida State University.

Simons, H. D., Van Rheenen, D. and Covington, M. V. (1999). Academic motivation and the student-athlete. Journal of College Student Development, 40(2), 151-162.

Sorkkila, M., Ryba, T.V., Aunola, K., Selänne, H. and Salmela-Aro, K. (2020). Sport burnout inventory-Dual career form for student-athletes: Assessing validity and reliability in a Finnish adolescent athlete sample. Journal of Sport and Health Science. 